\title{
CLINICAL AND RADIOGRAPHIC STUDY OF HEALING OF MANDIBULAR FRACTURES USING PLASMA RICH FIBRIN MEMBRANE WITH MINIPLATE FIXATION
}

\author{
Amany M. Al Rayess ${ }^{1} B D S$, Mostafa M. El Dibany² $P h D$, Lydia N. Melek ${ }^{3} P h D$.
}

\begin{abstract}
INTRODUCTION: The development of bioactive surgical additives to regulate the inflammation and increase the speed of the healing process is one of the greatest challenges in clinical research. Various materials and techniques have been developed to enhance the process of fracture bone healing and to fasten it.

Numerous techniques using autologous platelet concentrates have been developed and applied; platelet rich fibrin [PRF] being one of them, one that is completely autogenous in nature, simple and relatively inexpensive with a specific three-dimensional architecture of the fibrin. PRF has also shown increased levels of numerous cytokines and growth factors that influence bony regeneration.

OBJECTIVES: The aim in this study was to compare between fracture healing using miniplates with and without PRF membrane in bilateral mandibular fractures clinically and radiographically.

MATERIALS AND METHODS: all twelve patients had bilateral mandibular fractures. Each patient was treated as follows: (Study Group): The mandibular fracture on the right side was treated by using the conventional $2.0 \mathrm{~mm}$ miniplates and screws with placement of PRF membrane. (Control Group): The mandibular fracture on the left side was treated by using the conventional 2.0 mm miniplates and screws. Follow-up was carried out every week during the first month, then at three months, and six months postoperatively.

RESULTS: none of the patients in either of the groups had an infection or signs of nonunion within the follow- up period. There was no statistically significant difference in the mean value of pain score between the fractures in the two groups. In both groups, edema was limited to the area of operation and resolved completely by the end of 4th week postoperatively. On immediate, 3 and 6 months postoperatively, the mean bone density in the study group was statistically significantly higher than the control group, but the percentage change in the bone density from immediate postoperative to 3 months, immediate postoperative to 6 months and from 3 to 6 months was not statistically significant comparing the two groups
\end{abstract}

CONCLUSIONS: PRF application on the fracture line in the mandible may be helpful in improvement of the fracture healing but comparing the two groups, the pattern of improvement was nearly the same along time.

KEYWORDS: Alveolar bone, Fish oil, Induced rheumatoid arthritis, Freund's complete adjuvant

1- BDS, Alexandria University, Faculty of Dentistry, Alexandria University.

2- Professor at Department of Oral and Maxillofacial Surgery, Faculty of Dentistry, Alexandria University

3- Lecturer at Department of Oral and Maxillofacial Surgery, Faculty of Dentistry, Alexandria University.

\section{INTRODUCTION}

Mandibular fractures comprise most of the injuries treated by an oral and maxillofacial surgeon (1).

Although the main causes of mandibular fractures are road crashes and violence, the relationship between these causes varies from one country to another (2).

Goals of mandibular fracture repair are to re-establish a stable occlusion, re-establish an adequate range of motion, restore facial and mandibular arch form, restore pain-free function, avoid internal derangement of the temporomandibular joint, and avoid growth disturbances of the mandible (3).

Generally, fracture healing involves complex processes of cell and tissue proliferation, migration, and differentiation. Growth factors, inflammatory cytokines, antioxidants, bone breakdown (osteoclast) and bone building (osteoblast) cells, hormones, amino acids, and uncounted nutrients are recognized as the main players of complex processes in the fracture healing (4). An adequate blood supply is mandatory for fracture healing, therefore, anything that diminishes the blood flow; such as smoking or poor circulation, slows the healing process. Also, the trauma from the fracture itself creates a biochemical burst of pro-oxidants (free radicals), causing oxidative stress that can overwhelm the body's antioxidant reserves. Angiogenesis is considered a crucial step in the healing of a fracture by forming new blood vessels resulting in an improved blood supply at the defect site. Vascular endothelial growth factor (VEGF) has a driving force behind endothelial cells. VEGF receptor-2; found in endothelial cells and responsible for the formation of new blood vessels, is considered essential to the success of healing of a fracture (4).

The development of bioactive surgical additives to regulate the inflammation and increase the speed of healing process is one of the greatest challenges in clinical research. Various materials and techniques have been developed to enhance the bone healing process and fasten it (5).

Numerous techniques using autologous platelet concentrates have been developed and applied in oral and maxillofacial surgery.

As platelets play a crucial role not only in hemostasis but also in the wound healing process, the development of technologies to obtain platelet concentrates led to the formation of a kind of fibrin adhesive-concentrated Platelet-Rich Plasma (cPRP); however, because of legal restrictions on blood handling procedures, another family of platelet concentrates appeared in France; Platelet-Rich Fibrin (PRF) (6,7). Platelet-rich fibrin was first introduced in France by Choukroun et al in 2006 (6). It was considered a second-generation platelet concentrate as it is produced without any anticoagulants or gelifying agents (8). PRF is completely autogenous in nature, simple and relatively inexpensive with a specific three-dimensional architecture 
of the fibrin. PRF has also shown increased levels of numerous cytokines and growth factors that influence bony regeneration and maturation of soft tissue (9). Plateletderived growth factor- $\mathrm{AB}$ (PDGF-AB), transforming growth factor1 (TGF-1), and vascular endothelial growth factor (VEGF) (9) are key growth factors that are present in thrombocytes. After activation of the platelets which are trapped within fibrin matrix, growth factors are released and they stimulate the mitogenic response in the periosteum during normal wound healing to achieve bone repair (10). This study was carried out to evaluate the effect of PRF on the healing of mandibular fractures with miniplates fixation.

\section{MATERIALS AND METHODS}

\section{Informed Consent:}

Appropriate institutional ethical clearance from the Faculty Ethical Committee and written informed consent from the patients were obtained after detailed explanation of all the procedures. All patients were informed about the aim and objectives of the study.

This study was designed as a parallel, controlled, splitmouth, clinical trial. A total of 12 patients were included in this study from those admitted to the Oral and Maxillofacial Surgery Department, Faculty of Dentistry, Alexandria University, suffering from bilateral mandibular fractures that are indicated for surgical repair.

Each patient came in with bilateral mandibular fractures, one side treated as a study group and the other as a control group. Each patient was treated as follows: (Study Group): The mandibular fracture on the right side was treated by open reduction and direct fixation using the conventional $2.0 \mathrm{~mm}$ miniplates and screws with placement of PRF membrane. (Control Group): The mandibular fracture on the left side was treated by open reduction and direct fixation using the conventional $2.0 \mathrm{~mm}$ miniplates and screws.

\section{Inclusion criteria:}

Patient's age was from 20-50 years and both sexes were included. Patients suffered from bilateral mandibular fresh fractures requiring open reduction and internal fixation (not more than one week old). The sites of the mandibular fractures accepted were symphysis, Parasymphysis, body and angle).

\section{Exclusion criteria:}

Patients with relevant systemic disease contraindicating surgery, patients presented with infection at the fracture line and smokers.

\section{Materials}

a) PRF membrane.

b)Conventional titanium 2.0 miniplates and screws (7or $8 \mathrm{~mm}$ in length) (Antonhib, Germany).

\section{Methods}

A) Pre-operative Phase:

For all cases, thorough history taking, clinical and radiographic examinations were performed.

All patients were subjected to full clinical examination by inspection and palpation of the fracture sites both extraorally and intra-orally to detect the following: presence of edema, ecchymosis, soft tissue laceration, hemorrhage, derangement of occlusion, areas of tenderness, step deformities, mobility of the fractured segments, the site of the fracture and the state of the dentition.

Radiographic examination was accomplished for all patients at the time of admission. Standardized preoperative panoramic radiographs as in (Fig. 1) and any other necessary views were performed for each patient to assess the number and location of the line or lines of fracture, localize the inferior alveolar canal and any teeth in the fracture line.

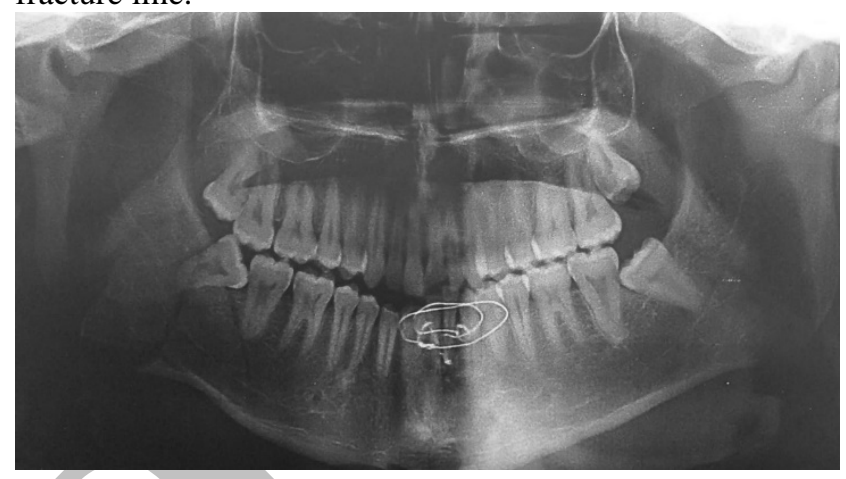

Figure (1): Panoramic view showing RT angle and LT parasymphysis fractures

\section{B) Operative Phase:}

All procedures were performed under general anesthesia and strict aseptic conditions. The oral cavity was first disinfected with povidone-iodine, as well as exrtraorally. Intermaxillary fixation (IMF) was used temporarily to adjust the occlusion. After exposing all the fracture lines through an intraoral incision; except for 3 cases that needed an extraoral incision to access angle fractures, the fractures were mobilized, and any soft tissue entrapped within the fracture lines were removed, and the bone reduction was done.

Fixation of the fractures was done as follows: (Study Group) as in (Fig. 2 A): The fracture on the right side was treated by reduction and fixation using conventional $2.0 \mathrm{~mm}$ miniplates and screws with placement of PRF membrane.(Control Group): as in (Fig. 2 B): The fracture on the left side was treated by reduction and fixation using conventional $2.0 \mathrm{~mm}$ miniplates and screws.
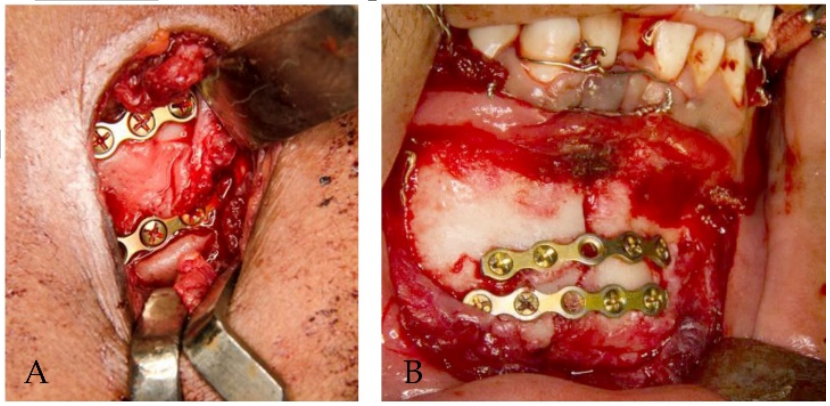

Figure (2): Showing operative phase.

Figure (2 A): Showing application of the two plates with PRF membrane on right angle (study group).

Figure (2 B): Showing application of two plates on left parasymphysis fracture (control group).

\section{Platelet Rich- Fibrin preparation:}

Twenty milliliters of patient's whole venous blood were collected in 2 sterile $10 \mathrm{ml}$ glass test tubes without anticoagulant. Then the test tubes were placed in a table centrifuge machine at 3000 rotations per minute (rpm) for 10 minutes. The resultant product consisted of the following three layers: the top most layer consisting of acellular platelet poor plasma (PPP), platelet rich fibrin layer (PRF) in the middle and red blood cells (RBCs) at the bottom. The PRF was then separated from PPP and RBC layer. 


\section{Platelet- rich fibrin as a membrane (Fig. 3)}

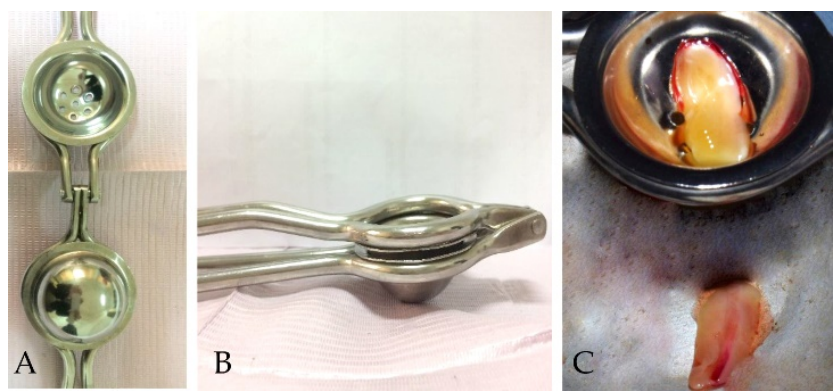

Figure (3): Showing preparation of the PRF membrane

Figure (3 A): A photograph showing compression device from inside.

Figure (3 B): A photograph showing compression device from outside

Figure (3 C): A photograph showing PRF before and after compression into a membrane.

The stainless steel PRF compression device developed for PRF membrane preparation composed of two spoonshaped parts, one has pinholes and the other is smooth. PRF was placed between them to secure the PRF and to drain the excess fluid when compressed.

After checking the correct reduction of the fracture and the stability of the internal fixation, the IMF was removed and the wound was closed in layers using polyglycolic polylactic 3-0 suture material (Vicryl, Ethicon, Cornelia, GA, USA) for deep layers and 4-0 polypropylene suture material (Prolene, Ethicon, Cornelia, GA, USA)for skin layer (Pterygomasseteric sling, platysma, subcutaneous tissue, and skin) in cases of extraoral incisions, and with polyglycolic polylactic 3-0 suture material in case of intraoral incisions.

\section{C) Postoperative Phase:}

The antibiotic regimen prescribed post-operatively was as follows: $875 \mathrm{mg}$ of amoxicillin: $125 \mathrm{mg}$ clavulanic acid (Augmentin, GlaxoSmithKline, UK) 1gm/12hours orally for 5 days. Metronidazole $500 \mathrm{mg}$ (Flagyl, Sanofi-Aventis, Egypt) every eight hours for 5 days orally. Anti-edematous agent, in the form $\alpha$ - chymotrypsin ampoules ( $\alpha$ chymotrypsin, Leurquin, France) was prescribed once daily for 5 days. Analgesic: diclofenac potassium (Cataflam, Novartis, Switzerland) (50 mg/8 hours) prescribed for 5 days. All patients were instructed to rinse their mouths using an antiseptic mouthwash. All patients were advised to stick to postoperative care instructions to prevent postoperative complications. Dressing change was done by nursing staff on daily basis. Sutures were removed after 5 to 7 days.

D) Follow-up Phase:

Follow-up was carried out every week during the first month, then at three months, and six months postoperatively. The evaluated points were soft tissue healing, pain, edema, trismus, sensory nerve function.

Finally, cone beam computed tomography (CBCT) was performed immediately postoperative, at 3 months and at 6 months consequently to evaluate:

1-The adequacy of the reduction of the fractured segment.

2-The Progress of the healing process.
3-The mean bone density at the site of the fracture line by using 4 points at each region of interest [ROI]. The mean bone density at the site of fracture was calculated by measuring the bone density at 4 points distributed inside the fracture line then taking their mean value to determine the mean bone density.

\section{Statistical analysis:}

All data obtained were statistically analyzed and represented in the form of tables and graphs using the Statistical Package for Social Science. (SPSS)

\section{RESULTS}

In the present study twelve patients, 10 males and 2 females, age ranging from 20 to 50 years were included with a mean of 23.92 \pm 7.01 . The cause of trauma was road traffic accident in 9 patients, while 2 patients were due to fall from a height and 1 patient due to violence.

In this study, the distribution of the fracture site was different from one case to another and as a result they were different in the size and number of plates and screws (Table 1).

Table (1): The site of the fracture and size of plates $($ no=12).

\begin{tabular}{|c|c|c|}
\hline No. & Site of the fracture & Size of plates \\
\hline 1 & $\begin{array}{c}\text { Right parasymphysial } \\
\text { Left angle }\end{array}$ & $\begin{array}{l}2 \text { plates with } 4 \text { holes } \\
1 \text { plate with six holes }\end{array}$ \\
\hline 2 & $\begin{array}{l}\text { right body } \\
\text { left body }\end{array}$ & $\begin{array}{l}2 \text { plates with } 4 \text { and } 5 \text { holes } \\
2 \text { plates with } 5 \text { and } 6 \text { holes }\end{array}$ \\
\hline 3 & $\begin{array}{c}\text { Right angle } \\
\text { Left parasymphysial }\end{array}$ & $\begin{array}{l}2 \text { plates with } 8 \text { holes } \\
2 \text { plates with } 5 \text { holes }\end{array}$ \\
\hline 4 & $\begin{array}{c}\text { Right body } \\
\text { Left parasymphysial }\end{array}$ & $\begin{array}{l}2 \text { plates with } 5 \text { holes } \\
2 \text { plates with } 5 \text { holes }\end{array}$ \\
\hline & $\begin{array}{c}\text { Right angle } \\
\text { Left parasymphysial }\end{array}$ & $\begin{array}{l}1 \text { plate with } 4 \text { holes } \\
1 \text { plate with } 6 \text { holes }\end{array}$ \\
\hline 6 & $\begin{array}{c}\text { Right angle } \\
\text { Left parasymphysial }\end{array}$ & $\begin{array}{l}2 \text { plates with } 4 \text { and } 5 \text { holes } \\
2 \text { plates with } 4 \text { and } 5 \text { holes }\end{array}$ \\
\hline 1 & $\begin{array}{c}\text { Right body } \\
\text { Left parasymphysial }\end{array}$ & $\begin{array}{l}2 \text { plates with } 5 \text { holes } \\
2 \text { plates with } 5 \text { holes }\end{array}$ \\
\hline 8 & $\begin{array}{c}\text { Right angle } \\
\text { Left parasymphysial }\end{array}$ & $\begin{array}{l}2 \text { plates with } 5 \text { and } 6 \text { holes } \\
2 \text { plates with } 4 \text { and } 5 \text { holes }\end{array}$ \\
\hline 9 & $\begin{array}{c}\text { Right angle } \\
\text { Left parasymphysial }\end{array}$ & $\begin{array}{l}2 \text { plates with } 4 \text { and } 5 \text { holes } \\
2 \text { plates with } 4 \text { and } 5 \text { holes }\end{array}$ \\
\hline 10 & $\begin{array}{c}\text { Right angle } \\
\text { Left parasymphysial }\end{array}$ & $\begin{array}{l}2 \text { plates with } 5 \text { holes } \\
2 \text { plates with } 5 \text { holes }\end{array}$ \\
\hline 11 & $\begin{array}{c}\text { Right parasymphysial } \\
\text { Left angle }\end{array}$ & $\begin{array}{l}2 \text { plates with } 4 \text { holes } \\
2 \text { plates with } 5 \text { holes }\end{array}$ \\
\hline 12 & $\begin{array}{c}\text { Right body } \\
\text { Left parasymphysial }\end{array}$ & $\begin{array}{l}2 \text { plates with } 5 \text { holes } \\
2 \text { plates with } 5 \text { holes }\end{array}$ \\
\hline
\end{tabular}

Postoperative clinical follow- up was performed to evaluate pain, edema, surgical wound condition, maximum mouth opening, state of occlusion and nerve function.

\section{Pain (Table 2)}

Pain intensity was decreased in all cases across the followup period where pain intensity score scaled from 0 (No pain) to 3 (Most severe pain) according to Visual Analogue Scale After 1 week: The mean value of pain score in the study group was $1.25 \pm 0.4$ while in the control group was $1.17 \pm$ 
0.58 , which was not statistically significant as p-value $=0.564$. $(\mathrm{P} \leq 0.05)$

After 2 weeks: The mean value of pain score in the study group was $0.50 \pm 0.52$ while in the control group was 0.25 \pm 0.45 , which was not statistically significant as $p$-value $=0.083 .(\mathrm{P} \leq 0.05)$

Table (2):Comparison between the two studied groups according to pain $(\mathrm{n}=12)$.

\begin{tabular}{|c|c|c|}
\hline Pain & $\overline{1^{\text {st }} \text { week }}$ & $2^{\text {nd }}$ week \\
\hline $\begin{array}{l}\text { Right with PRF } \\
\text { Min. - Max. } \\
\text { Mean } \pm \text { SD. } \\
\text { Median } \\
\text { IQR }\end{array}$ & $\begin{array}{c}1.0-2.0 \\
1.25 \pm 0.45 \\
1.0 \\
1.0-1.75\end{array}$ & $\begin{array}{c}0.0-1.0 \\
0.50 \pm 0.52 \\
0.50 \\
0.0-1.0\end{array}$ \\
\hline$p_{1}$ & \multicolumn{2}{|c|}{$0.003^{*}$} \\
\hline $\begin{array}{l}\text { Left without PRF } \\
\text { Min. - Max. } \\
\text { Mean } \pm \text { SD. } \\
\text { Median } \\
\text { IQR }\end{array}$ & $\begin{array}{c}0.0-2.0 \\
1.17 \pm 0.58 \\
1.0 \\
1.0-1.75\end{array}$ & $\begin{array}{c}0.0-1.0 \\
0.25 \pm 0.45 \\
0.0 \\
0.0-0.75\end{array}$ \\
\hline$p_{1}$ & \multicolumn{2}{|c|}{$\frac{1}{0.001^{*}}$} \\
\hline $\mathbf{Z}$ & 0.577 & 1.732 \\
\hline $\mathbf{p}_{2}$ & 0.564 & 0.083 \\
\hline
\end{tabular}

$\mathrm{p}_{1}$ : $\mathrm{p}$ value for Wilcoxon signed ranks test for comparing between $1^{\text {st }}$ week and $2^{\text {nd }}$ week in each side

$\mathrm{Z}, \mathrm{p}_{2}$ : $\mathrm{Z}$ and $\mathrm{p}$ values for Wilcoxon signed ranks test for comparing between the two sides in each period

*: Statistically significant at $\mathrm{p} \leq 0.05$

\section{Postoperative edema/swelling}

In both groups, edema was limited to the area of operation and resolved completely in all cases by the end of 4th week postoperatively.

\section{Surgical wound}

Wound healing went uneventful for all cases in both surgical sides and no infection nor wound dehiscence were detected.

\section{State of occlusion}

The examination of occlusion revealed normal occlusion and normal intercuspal relation; there was no need for selective grinding in any of the cases.

\section{Postoperative trismus}

The maximal inter-incisal opening was measured between maxillary and mandibular central incisors using a ruler preoperatively, then on the second postoperative day, after one week, 2weeks, 4 weeks, 6weeks, 3 and 6 months postoperatively.

Preoperative: The mean value of maximum mouth opening score was $21.67 \pm 5.37 \mathrm{~mm}$.

2nd day postoperatively: The mean value of maximum mouth opening score was $15.42 \pm 4.50 \mathrm{~mm}$, which was statistically significant when compared to the baseline as pvalue $=0.026$. $(\mathrm{P} \leq 0.05)$

1st week postoperatively: The mean value of maximum mouth opening score was16.58 $\pm 4.32 \mathrm{~mm}$, which was not statistically significant when compared to the baseline as pvalue $=0.058 .(\mathrm{P} \leq 0.05)$

2nd week: The mean value of maximum mouth opening score was19.58 $\pm 4.98 \mathrm{~mm}$, which was not statistically significant when compared to the baseline at p-value $=0.391 .(\mathrm{P} \leq 0.05)$

4th week postoperatively: The mean value of maximum mouth opening score was $27.83 \pm 9.83 \mathrm{~mm}$, which was not statistically significant when compared to the baseline at pvalue $=0.082 .(\mathrm{p} \leq 0.05)$

3rd month postoperatively: The mean value of maximum mouth opening score was $38.67 \pm 7.74 \mathrm{~mm}$, which was statistically significant when compared to the baseline at pvalue $=0.005$. $(\mathrm{P} \leq 0.05)$

6th month postoperatively: The mean value of maximum mouth opening score was $48.22 \pm 6.88 \mathrm{~mm}$, which was statistically significant when compared to the baseline at pvalue $=0.002$. $(\mathrm{P} \leq 0.05)$

\section{Nerve function}

Sensory impairment of the lower lip sensation was detected in 3 cases preoperatively due to the trauma itself and in 2 cases postoperatively.

One of the cases did not regain normal sensation by the end of the 6 months postoperative follow-up period in an angle fracture on the right side (study group) and he was a diabetic.

\section{Radiographic data}

Postoperative cone beam computed tomography (CBCT) that was performed within the first two days postoperatively showed good reduction in all cases, and proper alignment of the osseous borders of the mandible.

Evaluation of bone density (Table 3)

Table (3):Comparison between the two studied groups according to bone density $(n=12)$.

\begin{tabular}{||c|c|c|c||}
\hline \multirow{2}{*}{ Bone Density } & \multicolumn{3}{|c|}{ Postoperative } \\
\cline { 2 - 4 } & $\begin{array}{c}\text { Immediatel } \\
\text { y }\end{array}$ & 3 months & 6 months \\
\hline Right with PRF & & & \\
Min. - Max. & $177.0-$ & $407.0-$ & $590.0-$ \\
& 457.0 & 639.0 & 1055.0 \\
Mean \pm SD. & $314.0 \pm$ & $547.83 \pm$ & $797.0 \pm$ \\
Median & 109.13 & 74.68 & 169.91 \\
IQR & 284.50 & 555.50 & 775.0 \\
& $236.0-$ & $538.0-$ & $640.0-$ \\
\hline Sig. & 445.0 & 592.0 & 947.0 \\
\hline Left without PRF & $\mathrm{p}_{1}=0.002^{*}, \mathrm{p}_{2}=0.002^{*}, \mathrm{p}_{3}=0.002^{*}$ \\
\hline Min. - Max. & $123.0-$ & $256.0-$ & $393.0-$ \\
& 352.0 & 564.0 & 729.0 \\
Mean \pm SD. & $182.67 \pm$ & $374.67 \pm$ & $567.50 \pm$ \\
Median & 80.68 & 109.75 & 118.78 \\
& 152.0 & 368.50 & 557.0 \\
IQR & $144.0-$ & $261.0-$ & $487.0-$ \\
\hline Sig. & 173.0 & 430.0 & 682.0 \\
\hline Z & $3.066^{*}$ & $3.076^{*}$ & $3.105^{*}$ \\
\hline & $0.002^{*}$ & $0.002^{*}$ & $0.002^{*}$ \\
\hline \multicolumn{3}{|c|}{$0.002^{*}, \mathrm{p}_{2}=0.002^{*}, \mathrm{p}_{3}=0.002^{*}$} \\
\hline
\end{tabular}

$\mathrm{Z}$, $\mathrm{p}$ : $\mathrm{Z}$ and $\mathrm{p}$ values for Wilcoxon signed ranks test for comparing between the two sides in each period

$\mathrm{p}_{1}$ : $\mathrm{p}$ value for comparing between Immediately Postoperative and 3 months

$\mathrm{p}_{2}$ : $\mathrm{p}$ value for comparing between Immediately Postoperative and 6 months

$\mathrm{p}_{3}$ : $\mathrm{p}$ value for comparing between 3 months and 6 months *: Statistically significant at $\mathrm{p} \leq 0.05$

Immediate postoperative period: The mean difference in the study group was $314.0 \pm 109.13$ voxel value (VV) while in the control group was $182.67 \pm 80.68 \mathrm{VV}$, which was statistically significant at $\mathrm{p}$ - value $=0.002(\mathrm{p} \leq 0.05)($ Fig. 4). 
After 3 months: The mean difference in the study group was $547.83 \pm 74.68 \mathrm{VV}$ while in the control group was $374.67 \pm$

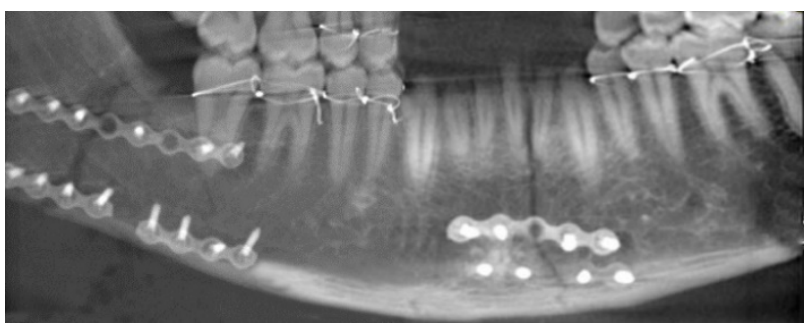

Figure (4): Immediate postoperative CBCT showing extraction of lower right 8 and then reduction and fixation of right angle and left parasymphysis fractures $109.75 \mathrm{VV}$, which was statistically significant at $\mathrm{p}$-value $=0.002$. $(\mathrm{p} \leq$ 0.05) (Fig. 5).

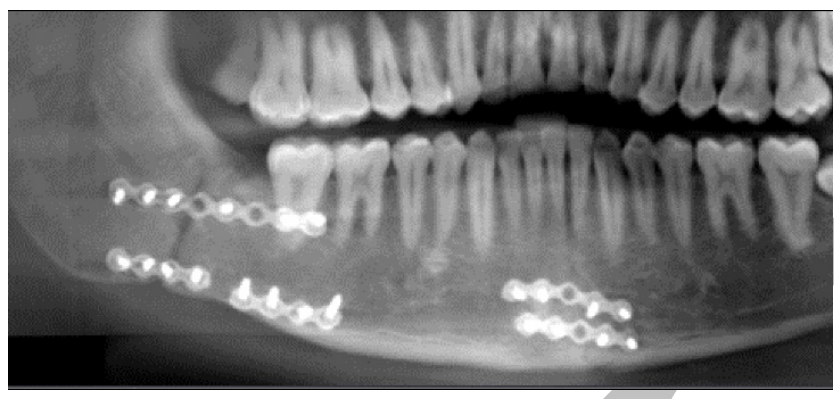

Figure (5): Postoperative CBCT after 3 months showing progress of healing in right angle and left parasymphysis fractures.

After 6 months: The mean difference in the study group was $797.0 \pm 169.91 \mathrm{VV}$ while in the control group was $567.50 \pm$ $118.78 \mathrm{VV}$, which was statistically significant at $\mathrm{p}$-value $=$ 0.002. ( $\mathrm{p} \leq 0.05)$ (Fig. 6).

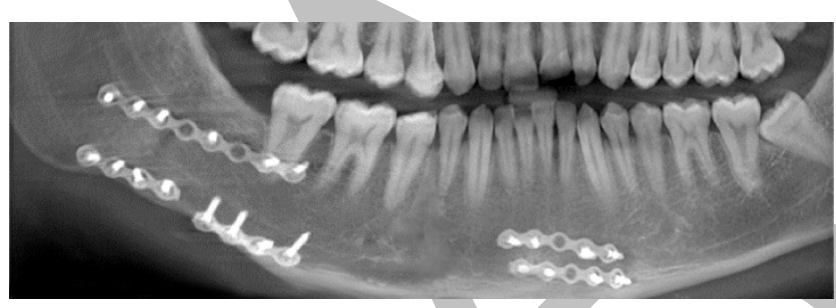

Figure (6): Showing postoperative CBCT after 6 months showing progress of healing and disappearing of the fracture line in right angle and left parasymphysis fractures.

\section{Evaluation of \% Change of bone density}

The percentage change in the bone density from immediate postoperative to 3 months, immediate postoperative to 6 months and from 3 to 6 months was not statistically significant comparing the two groups.

\section{DISCUSSION}

Patients included in the present study suffering from mandibular fractures were lying within the age group 20 50 years old. The mean age was $23.92 \pm 7.01$ years old which is higher than Sakr et al (11) who reported a mean age of 22 years but lower than Bergh et al (12) and Barbosa de Lima et al (13) who reported a mean age of 32. It is thought that this result is due to the fact that young adults represent a large mass in our country and they actively participate in outdoor activities without submitting to safety rules like seat belts in cars and wearing helmets when riding motorbikes. In our study, road traffic accidents were found to be the most frequent cause of fractures accounting for $75 \%$ of the cases, which was in agreement with Sakr et al (11) and with Sirimaharaj and Pyungtanasup (14).

This clinical trial with this criterion such as split-mouth technique and the fixation of the site of the PRF application could increase the strength of this study and decrease the bias.

Regarding the postoperative pain, the latter was assessed using a visual analogue scale (VAS). There was no significant difference between the two groups which was in contrast to Kumar et al (15) who assessed the effect of platelet-rich fibrin (PRF) on postoperative pain in mandibular third molar extraction sockets and found that the application of PRF decreased the severity of immediate post-operative sequels. The difference between our study and this one may be because of the fact that in our study, the patient had two surgical wounds so it was difficult for him/ her to give an accurate score.

In both groups, edema was limited to the area of operation and resolved completely in all cases by the end of 4th week postoperatively.

In this study, the postoperative trismus measurements showed a significant difference in some periods and it was obvious on the 2 nd day preoperatively due to the pain related to the fracture and due to the spasm of the muscles of mastication, and this spasm was found to increase postoperatively. This Trismus was found to significantly decrease with time which was found to be in agreement with Kumar et al (15).

Concerning nerve injury in our study, only one case did not regain normal sensation after 6 months because the fracture was already in one of the inferior alveolar nerve (IAN) bearing sites, the angle, and there was a severe displacement before the operation was found to be in agreement with Tay et al (16) who found that particularly, the odds of IAN injury for a fracture located at an IANbearing sites were 3.13 times the odds when compared to a non-IAN bearing sites.

Another reason might be that the patient was diabetic, so the nerve is already negatively affected by that disease which was in agreement with Kennedy and Zochodne (17) who studied the effect of diabetes mellitus on peripheral nerve regeneration.

In this study, radiographic follow-up was performed with CBCT radiograph to measure the bone density. This was found to be in agreement with Scarfe et al (18) and Angelopouloset al (19) in their studies which demonstrated a strong correlation between grayscale values of CBCT images and bone densities. This has implications for potential quantitative radiological approaches to determine bone density from CBCT images.

The present study showed that the mean bone density in the study group was higher than the control group. This finding proved to be statistically significant throughout the follow up period but the percentage change in the bone density from immediate postoperative to 3 months, immediate postoperative to 6 months and from 3 to 6 months was not statistically significant comparing the two groups. This means that the mean bone density is significantly higher in the study group but the pattern of 
improvement is nearly the same throughout time comparing the two groups.

A lot of studies support the PRF as a healing biomaterial because the high levels of growth factors in the PRF which accelerates the proliferation of osteoprogenitor cells. Moreover, the fibrin seems to be a relevant matrix to support osteoblastic growth and differentiation, that is why it is used frequently during bone tissue-engineering experimentations (20).

A stainless steel PRF compression device was used instead of gauze to prepare a more clinically effective PRF membrane having the following criteria: 1 ) growth factors stored in platelets should be retained to stimulate the cells of the surrounding host tissues; 2) platelets should be preserved in the fibrin meshwork with minimal damage and 3) the three-dimensional fibrin meshwork construction should be preserved as a scaffold for surrounding host cells and that coincides with Kobayashi et al (21) and $\mathrm{Su}$ et al (22).

Our result was in agreement with Zhang et al (23) in the study which evaluated the influence of PRF on bone regeneration in sinus augmentation in combination with a xenograft, deproteinized bovine bone. The percentage of new bone formation in the PRF group was about 1.4 times of that in control, while the percentage of residual bone substitute in the control group was about 1.5 times higher as that in the PRF group. The percentage of contact length between newly formed bone and bone substitute in the PRF group was higher than the control group. They concluded that there were no significant statistical differences between the two groups were found in these observed parameters after a healing period of 6 months.

Al.Khawlani et al (24) conducted a study which to evaluate the validity of application of the platelet-rich fibrin versus platelet-rich plasma on the outcome of the mandibular fracture. They concluded that PRP and PRF seem to aid acceleration of bone healing in mandibular fractures, but PRF more efficient than PRP in bone formation.

In a recent study by Dülgeroglu and Metineren (25) conducted to evaluate the effect of PRF on long bone healing experimental rat model. The results indicated that platelet rich fibrin is an efficient biomaterial in fracture healing and that it increases the amount of osseous tissue formation.

Furthermore, Faot et al (26) conducted a study about the effect of PRF membranes on bone healing in rabbit tibiae bone defects. He found that PRF treatment did not enhance bone regeneration in these non-critical size defects after 28 days. This rabbit model encountered several limitations that jeopardize a full understanding of the effects of L-PRF treatment, such as the lack of fixation devices to stabilize the PRF clot and potential of membrane dislodgement due to high mobility of the animals especially after the 1st week. Also, the anatomy of the tibia does not favor retention of the L-PRF membrane and the period of evaluation have to be extended.

There were some limitations and different variables that affected our results as difficulties in the standardization of the conditions in terms of the fracture type and surgical approach used.

There were some obstacles related to the extended time of the operation due to the preparation of the PRF membrane.

\section{CONCLUSION}

PRF application on the fracture line in the mandible may be helpful in improvement of the fracture healing but comparing the two groups, the pattern of improvement was nearly the same along time.

\section{CONFLICT OF INTEREST}

The authors declare that they have no conflicts of interest.

\section{REFERENCES}

1. Devadiga A, Prasad KSV. Epidemiology of Maxillofacial Fractures and Concomitant Injuries in a Craniofacial Unit: A Retrospective Study. Internet J Epidemiol. 2008; 5: $1-7$.

2. Sojot AJ, Meisami T, Sandor GK, Clokie CM. The epidemiology of mandibular fractures treated at the Toronto general hospital: A review of 246 cases. J Can Dent Assoc. 2001; 67: 640-4.

3. Andersson L, Kahnberg KE, Pogrel MA. Oral and maxillofacial surgery. Chichester, West Sussex, U.K.: Wiley-Blackwell; 2010. P. 883.

4. Fonseca RJ. Oral and Maxillofacial Trauma. 4th ed. St. Louis: Saunders; 2013. P. 14-16.

5. Prakash S, Thakur A. Platelet Concentrates Past, Present, and Future. J Maxillofac Oral Surg. 2011; 10: 45-9.

6. Choukroun J, Diss A, Simonpieri A, Girard MO, Schoeffler C, Dohan SL, et al. Platelet-rich fibrin (PRF): A second-generation platelet concentrate. Part V: Histologic evaluations of PRF effects on bone allograft maturation in sinus lift. Oral Surg Oral Med Oral Pathol Oral Radiol Endod. 2006; 101: 299-303.

7. Anitua E, Sánchez M, Nurden AT, Nurden P, Orive G, Andía I. New insights into and novel applications for platelet-rich fibrin therapies. Trends Biotechnol. 2006; 24: 227-34.

8. Tunali M, Özdemir H, Küçükodaci Z, Akman S, Firatli E. In vivo evaluation of titanium-prepared platelet-rich fibrin (T-PRF): A new platelet concentrate. Br J Oral Maxillofacial Surg. 2013; 51: 438-43.

9. Naik B, Karunakar P, Jayadev M, Marshal VR. Role of Platelet rich fibrin in wound healing: A critical review. J Conserv Dent. 2013; 16: 284-93.

10. Dohan DM, Choukroun J, Diss A, Dohan SL, Dohan AJJ, Mouhyi J, et al. Platelet-rich fibrin (PRF): A second-generation platelet concentrate. Part II: Plateletrelated biologic features. Oral Surg Oral Med Oral Pathol Oral Radiol Endod. 2006; 101: 45-50.

11. Sakr K, Farag IA, Zeitoun IM. Review of 509 mandibular fractures treated at the University Hospital, Alexandria, Egypt. Br J Oral Maxillofac Surg. 2006; 44: 107-11.

12. van den Bergh B, Heymans MW, Duvekot F, Forouzanfar T. Treatment and complications of mandibular fractures: a 10-year analysis. J Craniomaxillofac Surg 2012; 40: e108-11.

13. de Lima APCB, Semenoff TADV, da Silva NF, Naclerio-Homem MG, Borba AM, Borges AH, et al. Epidemiological analysis of facial fractures. Sci J Dent. 2015; 2: 1-4.

14. Sirimaharaj W, Pyungtanasup K. The epidemiology of mandibular fractures treated at Chiang Mai University Hospital: A review of 198 cases. J Med Assoc Thail. 
2008; 91: 868-74.

15. Kumar N, Prasad K, Ramanujam L, K R, Dexith J, Chauhan A. Evaluation of Treatment Outcome after Impacted Mandibular Third Molar Surgery with the Use of Autologous Platelet-Rich Fibrin: A Randomized Controlled Clinical Study. J Oral Maxillofac Surg. 2015; 73: 1042-9.

16. Tay AB, Lai JB, Lye KW, Wong WY, Nadkarni NV, Li $\mathrm{W}$, et al. Inferior Alveolar Nerve Injury in TraumaInduced Mandible Fractures. J Oral Maxillofac Surg. 2015; 73: 1328-40.

17. Kennedy JM, Zochodne DW. Impaired peripheral nerve regeneration in diabetes mellitus. J Peripher Nerv Syst. 2005; 10: 144-57.

18. Scarfe WC, Farman AG, Sukovic P. Clinical applications of cone-beam computed tomography in dental practice. J Can Dent Assoc. 2006; 72: 75-80.

19. Angelopoulos C, Scarfe WC, Farman AG. A Comparison of Maxillofacial CBCT and Medical CT. Atlas Oral Maxillofac Surg Clin North Am. 2012; 20: 117.

20. Ng AM, Saim AB, Tan KK, Tan GH, Mokhtar SA, Rose $\mathrm{IM}$, et al. Comparison of bioengineered human bone construct from four sources of osteogenic cells. J Orthop Sci. 2005; 10: 192-9.

21. Kobayashi M, Kawase T, Horimizu M, Okuda K, Wolff LF, Yoshie H. A proposed protocol for the standardized preparation of PRF membranes for clinical use. Biologicals. 2012; 40: 323-9.

22. Su CY, Kuo YP, Tseng YH, Su CH, Burnouf T. In vitro release of growth factors from platelet-rich fibrin (PRF): a proposal to optimize the clinical applications of PRF. Oral Surg Oral Med Oral Pathol Oral Radiol Endod. 2009; 108: 56-61.

23. Zhang Y, Tangl S, Huber CD, Lin Y, Qiu L, Rausch-Fan $X$. Effects of Choukroun's platelet-rich fibrin on bone regeneration in combination with deproteinized bovine bone mineral in maxillary sinus augmentation: A histological and histomorphometric study. J CranioMaxillofacial Surg. 2012; 40:321-8.

24. Al-Khawlani E, Adly OA, Hamed TA, Abass AH, Abdelmabood AA. Clinical and radiographic evaluation of platelet-rich fibrin gel on the outcome of mandibular fracture. Egyptian J Oral Maxillofac Surg. 2014; 5: 7783.

25. Dülgeroglu TC, Metineren H. Evaluation of the Effect of Platelet-Rich Fibrin on Long Bone Healing: An Experimental Rat Model. Orthopedics. 2017; 40: e47984.

26. Faot F, Deprez S, Vandamme K, Camargos GV, Pinto $\mathrm{N}$, Wouters J, et al. The effect of L-PRF membranes on bone healing in rabbit tibiae bone defects: micro-CT and biomarker results. Sci Rep. 2016; 7: 1-10. 